\title{
The Impact of the Twin Peaks Model on the Insurance Industry
}

D Millard*

\section{P.E.R}

Pioneer in peer-reviewed, open access online law publications.

Author

Daleen Millard

Affiliation

University of Johannesburg, South Africa

Email dmillard@uj.ac.za

Date published

14 November 2016

Editor Prof S du Toit

How to cite this article

Millard D "The Impact of the Twin Peaks Model on the Insurance Industry" PER / PELJ 2016(19) DOI

http://dx.doi.org/10.17159/17273781/2016/v19i0a1503

\section{Copyright}

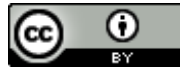

DOI

http://dx.doi.org/10.17159/17273781/2016/v19i0a1503

\section{Abstract}

Financial regulation in South Africa changes constantly. In the quest to find the ideal regulatory framework for optimal consumer protection, rules change all the time and international trends have an important influence on lawmakers nationally. The Financial Sector Regulation Bill, also known as the "Twin Peaks" Bill, is the latest invention from the table of the legislature, and some expect this Bill to have far-reaching consequences for the financial services industry. The question is, of course, whether the current dispensation will change so quickly and so dramatically that it will literally be the end of the world as we know it or whether there will be a gradual shift in emphasis away from the so-called silo regulatory approach to an approach that distinguishes between prudential regulation on the one hand and market conduct regulation on the other. A further question is whether insurance as a financial service will change dramatically in the light of the expected twin peak dispensation. The purpose of this paper is to discuss the implications of the FSR Bill for the insurance industry. Instead of analysing the Bill feature for feature, the method that will be used in this enquiry is to identify trends and issues from 2014 and to discuss whether the Twin Peaks model, once implemented, can successfully eradicate similar problems in future. The impact of Twin Peaks will of course have to be tested, but at this point in time it may be very useful to take an educated guess by using recent cases as examples. Recent cases before the courts, the Enforcement Committee and the FAIS Ombud will be discussed not only as examples of the most prevalent issues of the past year or so, but also as examples of how consumer issues and systemic risks are currently being dealt with and how this may change with the implementation of the FSR Bill.

\section{Keywords}

Insurance; financial services providers; financial sector regulation; Financial Sector Regulation Bill; market conduct; prudential regulation; Twin Peaks; FAIS Ombud; Enforcement Committee; Treating Customers Fairly 


\section{Introduction}

The delicate balance between over-regulating and under-regulating is a matter that will not be settled in our time. To complicate matters, government has started to move away from the practice of so-called "silo" regulation and supervision, that focuses on supervision according to industry (such as banking and insurance), to a model which regulates according to function, for example systemic risk management and consumer treatment (the so-called "Twin Peaks" model). ${ }^{1}$

The Financial Sector Regulation Bill (FSR Bill) is the first step towards the implementation of the Twin Peaks model. After the publication of the first draft bill a period was allowed for comment from 13 December 2013 to 7 March 2014. Several comments were received on various aspects of the draft bill, and on matters pertaining to insurance and intermediaries. The Association for Savings and Investment South Africa (ASISA), the Financial Intermediaries Association of Southern Africa (FIA) and the South African Insurance Association (SAIA) made submissions on a number of issues, such as the definition of "financial crisis" in the draft bill. The revised version still does not contain a definition of "financial crisis" but now defines "systemic event" and "systemic risk", and chapter 2 of the Bill explains the Reserve Bank's powers and responsibilities in managing systemic risk and systemic events. ${ }^{2}$

The second draft of the FSR Bill took a number of other comments into account. For instance, the Bill no longer refers to "mono and dual" regulation by authorities. Rather, it provides that financial product providers will be regulated and supervised by the Prudential Authority and financial service providers will resort under the Financial Sector Conduct Authority. Furthermore, clause 2 of the Bill defines a financial product as follows:

(a) a participatory interest in a collective investment scheme;

(b) an interest, subscription, contribution, or commitment in a pooled fund;

(c) a long-term or a short-term policy, as defined in section 1(1) of the Long-term Insurance Act and section 1(1) of the Short-term Insurance Act, respectively;

* Daleen Millard. B luris, LLB, LLM (UP), LLD (UJ). Professor of Law, Department of Private Law, University of Johannesburg. Email: dmillard@uj.ac.za. This paper was presented at the University of Johannesburg's Annual Banking Law Update in May 2015. I am indebted to the panel, especially Prof Moellers from Germany, for his insights and comments. Many thanks also to Marieke Roos for her careful editing. Gilmour 2015 http://bit.ly/1T3KeT8.

National Treasury 2014 http://bit.ly/26XEGxB 3, 7. 
(d) a benefit provided by-

(i) a pension fund organisation as defined in section 1(1) of the Pension Funds Act, to the members of the organisation by virtue of membership; or

(ii) a friendly society as defined in section 1(1) of the Friendly Societies Act, to the members of the society by virtue of membership;

(e) a deposit as defined in section 1(1) of the Banks Act;

(f) a health service benefit provided by a medical scheme as defined in section 1(1) of the Medical Schemes Act, 1998 (Act No. 131 of 1998);

(g) a credit agreement;

(h) a facility, arrangement or system that is designated by the Minister in terms of subsection (2) in Regulations as being a "financial product";

(i) any combined product containing one or more of the financial products referred to in paragraphs (a) to $(\mathrm{h})$.

This definition corresponds with the current definition of "financial product" in the Financial Advisory and Intermediary Services Act (FAIS Act). ${ }^{3}$ The Prudential Authority will henceforth be responsible for supervising the safety and soundness of financial institutions that provide financial products, market infrastructures or payment systems. ${ }^{4}$ Prudential oversight is aimed to ensure that institutions meet their financial obligations to customers. $^{5}$

The other peak, the Financial Sector Conduct Authority, is expected to be responsible for fair treatment, integrity and education, and will supervise services performed in relation to financial products, foreign financial product, securities, market infrastructure or the payment system. ${ }^{6}$ What is important to note is that the definition of "financial service" is (quote) comprehensive and differs markedly from the current definition of "financial service" in the FAIS Act. ${ }^{7}$ "Financial service" in the FSR Bill means-

(a) in relation to a financial product, foreign financial product, securities, market infrastructure or the payment system as applicable-

(i) promotion, marketing or distribution;

(ii) providing advice, recommendations or guidance;

(iii) dealing or making a market;

3 Section 1(1) of the Financial Advisory and Intermediary Services Act 37 of 2002, "financial product".

4 Clauses 27-29 of the Financial Sector Regulation Bill [B34-2015] (FSR Bill).

5 The FSR Bill also allows the Minister in terms of s 215 and in accordance with $\mathrm{s}$ 231(3) to designate in Regulations as a "financial product" a category or type of facility, arrangement, or system that is not already regulated in terms of a financial sector law; and cannot be designated in Regulations in terms of another financial sector law to be regulated in terms of that financial sector law. This designation is aimed at furthering the objectives of the FSR Bill.

$6 \quad$ Clause 3 of the FSR Bill.

7 The current definition in $s$ 1(1) of the FAIS Act stipulates that a financial service "means any service contemplated in paragraph (a), (b) or (c) of the definition of 'financial services provider', including any category of such services". 
(iv) operating or managing, or providing administration services;

(v) services provided in relation to credit agreements, including legal services;

(vi) services provided by payment system participants;

(b) providing an intermediary service as defined in section 1(1) of the Financial Advisory and Intermediary Services Act;

(c) securities services provided by a regulated person as defined in section 1(1) of the Financial Markets Act;

(d) providing credit rating services as defined in section 1(1) of the Credit Rating Services Act, 2012 (Act No. 24 of 2012);

(e) the calculation of a financial benchmark;

(f) services related to an interest, subscription, contribution, or commitment in a pooled fund;

(g) services related to the buying and selling of foreign exchange;

(h) dealing with trust property, as defined in section 1 of the Financial Institutions (Protection of Funds) Act, 2001 (Act No. 23 of 2001), as a regular feature of business;

(i) a service that is designated by the Minister in terms of subsection (2) in Regulations as a financial service.

The purpose of this paper is to discuss the implications of the FSR Bill for the insurance industry. Instead of analysing the Bill feature for feature, the method that will be used in this enquiry is to identify trends and issues from 2014 and to discuss whether the Twin Peaks model, once implemented, can successfully eradicate similar problems in future. The impact of Twin Peaks will of course have to be tested, but at this point in time it may be very useful to take an educated guess by using recent cases as examples. Recent cases before the courts, the Enforcement Committee and the FAIS Ombud will be discussed not only as examples of the most prevalent issues of the past year or so, but also as examples of how consumer issues and systemic risks are currently being dealt with and how this may change with the implementation of the FSR Bill.

\section{PART I: CURRENT REGULATORY FRAMEWORK}

The South African insurance industry is highly regulated, which means that, apart from the common law, statutes, together with regulations and rules in terms of these statutes, are a very important source of insurance law. This means that in interpreting insurance contracts the starting point is always the applicable statute. But insurance legislation also regulates the way in which insurance companies should operate, and at the moment significant parts of the existing statutes are dedicated to these matters. In short, the Long-term Insurance Act (LTIA $)^{8}$ and the Short-term Insurance

$8 \quad$ Long-term Insurance Act 52 of 1998. 
Act $(\mathrm{STIA})^{9}$ regulate product-specific matters and the FAIS Act regulates the activities of advisors and intermediaries who sell insurance.

\section{Twin Peaks: Market conduct and the Financial Sector Conduct Authority}

Market conduct refers to the way in which financial services providers conduct their business, design and price their products, and treat their customers. This function is therefore primarily concerned with the relationship between insurance companies and policyholders and it is in this context that matters pertaining to advertising, compliance with product features and standards, claims handling and dispute resolution become relevant.

The discussion that follows provides an overview of the court cases and Ombud decisions of 2014 and views these against the Treating Customers Fairly Outcomes (TCF). The discussion will start with the Ombud decisions and will then move on to the court cases. But first, some background on TCF.

\section{TCF}

A search of the FSR Bill reveals that there is no specific clause that states that there will be such a thing as TCF. Rather, the so-called TCF principles are embedded in the proposed legislation and it is evident that the conduct of financial institutions will henceforth be measured against TCF principles. A perusal of a number of clauses of the FSR Bill makes this evident. For instance, clause 6 of the Bill postulates that it is the object of the proposed act

to achieve a financial system that works in the interests of financial customers, and supports balanced and sustainable economic growth in the Republic, by establishing, in conjunction with the other financial sector laws, a regulatory and supervisory framework that promotes-
(a) financial stability;
(b) the safety and soundness of financial institutions;
(c) the fair treatment and protection of financial customers;
(d) the efficiency and integrity of the financial system;
(e) the prevention of financial crime;
(f) financial inclusion; and
(g) confidence in the financial system. [Own emphasis.]

$9 \quad$ Short-term Insurance Act 53 of 1998. 
In addition, clause 52(a) states that the objective of the new Financial Sector Conduct Authority (FSCA) will be to ensure that financial institutions treat customers fairly ${ }^{10}$ and the functions of the FSCA are set out in accordance with these objectives. ${ }^{11}$

It is in fact clause 95(1)(c)(i) that authorises the FSCA to make conduct standards to ensure the protection and fair treatment of financial customers. Furthermore, sub-clause 2(a) specifies that in order to achieve this purpose and the other objectives (such as financial literacy), conduct standards will also set out fit and proper requirements and rules relating to the composition, roles and responsibilities of governing bodies of financial institutions ${ }^{12}$ and the standards of business conduct for financial institution representatives or mandataries. ${ }^{13}$ The embedded value of fairness is further evident from clause 95(1)(f), that specifies that there will be standards for the "promotion, marketing, distribution of or access to financial products, financial services, market infrastructures or payment systems". Furthermore, clause 95(g) envisages standards for disclosures in relation to financial products and services and 95(h) for giving advice, recommendations or guidance to financial customers in relation to financial products, financial services or in relation to financial planning.

The remainder of clause 95 makes it clear that there will be standards for ensuring that financial products or financial services suitable to the needs and circumstances of financial customers, ${ }^{14}$ that there are standards for financial products or financial services,$^{15}$ and that there are standards for contracts. ${ }^{16}$

While the current legal status of TCF is debatable, ${ }^{17}$ it is a fact that TCF is the new direction that will be followed in the financial services industry and that the new principles-based approach is one of the cornerstones of Twin Peaks. According to National Treasury,

the TCF framework is transforming the way in which the supervision of market conduct happens. Being implemented by the FSB, TCF is an

10 Other objectives include enhancing the efficiency and integrity of the financial system (clause 52 (b) of the FSR Bill) and providing financial customers and potential financial customers with financial education programmes, promoting financial literacy and financial capability (clause 52(c)).

11 Clause 52 of the FSR Bill.

12 Clauses 95(b)(ii) and (iii) of the FSR Bill.

13 Clause 95(e) of the FSR Bill.

14 Clause 95(i) of the FSR Bill.

15 Clause 95(j) of the FSR Bill.

16 Clause $95(\mathrm{~m})$ of the FSR Bill.

17 See Millard 2014 THRHR 547-566. 
activities-based, cross-cutting and outcomes-driven approach to regulation and supervision, designed to ensure that regulated financial institutions apply specific standards of fairness to all financial customers. ${ }^{18}$

What is clear is that financial institutions must demonstrate that they deliver specified outcomes to their customers. These outcomes are the following, namely:

- $\quad$ customers can be confident they are dealing with firms where TCF is central to the corporate culture;

- $\quad$ products and services marketed and sold in the retail market are designed to meet the needs of identified customer groups and are targeted accordingly;

- customers are provided with clear information and are kept appropriately informed before, during and after point of sale;

- where advice is given, it is suitable and takes account of customer circumstances;

- $\quad$ products perform as firms have led customers to expect, and service is of an acceptable standard and as they have been led to expect; and

- $\quad$ customers do not face unreasonable post-sale barriers imposed by firms to change product, switch providers, submit a claim or make a complaint. ${ }^{19}$

A closer look at these outcomes reveals that there are existing standards that aim to ensure fair outcomes. Outcome three that deals with clear information before, during and after point of sale and outcome four that deals with the suitability of advice are excellent examples. Section 8 of the General Code of Conduct for Authorised Financial Services Providers and Representatives (GCC) places an obligation on a provider other than a direct marketer to take reasonable steps to seek from the client appropriate and available information regarding the client's financial situation, financial product experience and objectives so that the provider

\footnotetext{
18 National Treasury 2014 http://www.treasury.gov.za/public\%20comments/FSR2014/ Treating\%20Customers\%20Fairly\%20in\%20the\%20Financial\%20Sector\%20Draft\% 20MCP\%20Framework\%20Amended\%20Jan2015\%20WithAp6.pdf 50.

19 National Treasury 2014 http://www.treasury.gov.za/public\%20comments/FSR2014/ Treating\%20Customers\%20Fairly\%20in\%20the\%20Financial\%20Sector\%20Draft\% 20MCP\%20Framework\%20Amended\%20Jan2015\%20WithAp6.pdf 51.
} 
can provide the client with appropriate advice. ${ }^{20} \mathrm{~A}$ provider must conduct an analysis for purposes of the advice and identify the product that is the most appropriate to the client's financial needs. ${ }^{21}$ What is more, section $8(2)$ of the GCC states that a provider must take reasonable steps to ensure that the client understands the advice and that the client is in a position to make an informed decision. Therefore, it is reasonably safe to say that many of the principles that are embodied by the TCF outcomes are already part of South African law. It is against this background that some of the past year's Ombud determinations, Enforcement Committee cases and high court cases will be discussed.

\section{PART II: OMBUD DETERMINATIONS}

\section{$1 \quad$ Mandate of the FAIS Ombud}

The FAIS Ombud is a statutory ombud that is constituted by virtue of section 20 of the FAIS Act. ${ }^{22}$ The FAIS Ombud derives its authority to adjudicate from the FAIS Act and more specifically from the Rules on Proceedings of the Office of the Ombud for Financial Services Providers, 2003 promulgated by virtue of section 26 of the FAIS Act. Because the FAIS Act deals with the activities of advisors and intermediaries in respect of all financial products as defined, it is not only insurance intermediaries, advisors and representatives who may fall under the FAIS Ombud's jurisdiction but also those who render any other service in relation to a financial product as defined by the FAIS Act. In addition, a client must first exhaust the internal complaint resolution system and procedures as set out by Part XI of the GCC. ${ }^{23}$ As it is, fairness is already a consideration in internal complaint resolution procedures and where disputes cannot be

20 Section 8(1)(a) of the General Code of Conduct for Authorised Financial Services Providers and Representatives (GCC).

21 Sections 8(1)(b) and (c) of the GCC.

22 This particular section provides as follows: "(1) There is an office to be known as the Office of the Ombud for Financial Services Providers. (2) The functions of the Office are performed by the Ombud for Financial Services Providers. (3) The objective of the Ombud is to consider and dispose of complaints in a procedurally fair, informal, economical and expeditious manner and by reference to what is equitable in all the circumstances, with due regard to - (a) the contractual arrangement or other legal relationship between the complainant and any other party to the complaint; and (b) the provisions of this Act. (4) When dealing with complaints in terms of sections 27 and 28 the Ombud is independent and must be impartial."

23 Section $17(\mathrm{~d})$ of Part XI of the GCC, titled "Basic principles of systems and procedures" stipulates that internal dispute resolution procedures should be based on fairness in ensuring that a resolution process should be fair to both clients, the provider and its staff. 
settled and are referred to the FAIS Ombud, the Ombud's mandate is to settle disputes. In terms of section $27(5)$ of the FAIS Act, the Ombud:

(a) may, in investigating or determining an officially received complaint, follow and implement any procedure (including mediation) which the Ombud deems appropriate, and may allow any party the right of legal representation;

(b) must, in the first instance, explore any reasonable prospect of resolving a complaint by a conciliated settlement acceptable to all parties;

(c) may, in order to resolve a complaint speedily by conciliation, make a recommendation to the parties, requiring them to confirm whether or not they accept the recommendation and, where the recommendation is not accepted by a party, requiring that party to give reasons for not accepting it: Provided that where the parties accept the recommendation, such recommendation has the effect of a final determination by the Ombud, contemplated in section 28(1);

(d) may, in a manner that the Ombud deems appropriate, delineate the functions of investigation and determination between various functionaries of the Office; and

(e) may, on terms specified by the Ombud, mandate any person or tribunal to perform any of the functions referred to in paragraph (d).

If either party rejects a recommendation, the Ombud provides the parties with a final determination, but the Ombud may also issue a determination without a recommendation. ${ }^{24}$ In making the determination, the Ombud has extensive powers and a determination may include the dismissal of the complaint or the upholding of the complaint. Where a complaint is upheld, this can be done either wholly or partially, which means that the Ombud may award an amount as fair compensation for any "financial prejudice" or "damage" suffered. The Ombud may also order the authorised financial services provider, representative or other party involved to what the Ombud may consider as appropriate. ${ }^{25}$ Finally, the Ombud may make any other order which a Court may make ${ }^{26}$ and a final determination may also include a cost order. ${ }^{27}$

\section{$2 \quad$ Fairness}

Rulings by the FAIS Ombud and any division of the High Court constitute precedents. Where the FAIS Ombud is required to make a determination where the main issue concerns a matter of law, the doctrine of precedent is suitable. However, the doctrine is less well suited to cases where the FAIS Ombud has to issue a determination that is fair to both the respondent (the insurer) and the complainant (the insured), since the

\footnotetext{
24 Moolman et al Financial Advisory and Intermediary Services Guide 223-224.

25 Moolman et al Financial Advisory and Intermediary Services Guide 223-224.

26 Moolman et al Financial Advisory and Intermediary Services Guide 223-224.

27 Moolman et al Financial Advisory and Intermediary Services Guide 223-224.
} 
concept of "fairness" depends on the particular circumstances of the dispute at hand. What is fair between $A$ and $B$ is not necessarily fair between $A$ and $C$, and in this respect it is submitted that the FAIS Ombud's scheme is seriously flawed. It is predicted that this will only become worse with the implementation of TCF, as considerations will be based more on fairness and less on the law.

If one considers the origins of TCF and the way in which these principles are enforced in the UK, it is evident that although there is a lot of scope for infusing the TCF principles in insurance law, these decisions should not be used as precedents. General reporting of the Financial Ombudsman Service FOS on their determinations has been one of the subjects under investigation by Lord Hunt. ${ }^{28}$ The arguments against detailed reporting are that the volumes of cases would be too large to manage, ${ }^{29}$ that there is a danger of seeing these decisions as precedent-setting, ${ }^{30}$ and that publication can "create false and undesirable misapprehensions". ${ }^{31}$ There was a recommendation that leading cases should be reported as case studies. However, some felt that Lord Hunt's proposed "FOSBOOK" in which cases would be reported would amount to "second-tier regulation". 32

Therefore, the practice of only reporting on findings in general and also anonymously is very different from the South African practice of making full judgments available to members of the public. ${ }^{33}$

\section{Jurisdiction of the Ombud}

The matter of reporting brings a second issue to the fore, and that is the jurisdiction of the FAIS Ombud. In the recent decision of the Appeal Board of the Financial Services Board in Sharemax Investments (Pty) Ltd (in Business Rescue) $v$ Siegrist, ${ }^{34}$ the Appeal Board ruled that the FAIS Ombud erred in joining Sharemax and four of its directors in a complaint procedure that was brought by two complainants, Siegrist and Bekker, against two financial advisors who advised the complainants to invest in the Sharemax-promoted Zambesi syndication. The Ombud, on her own

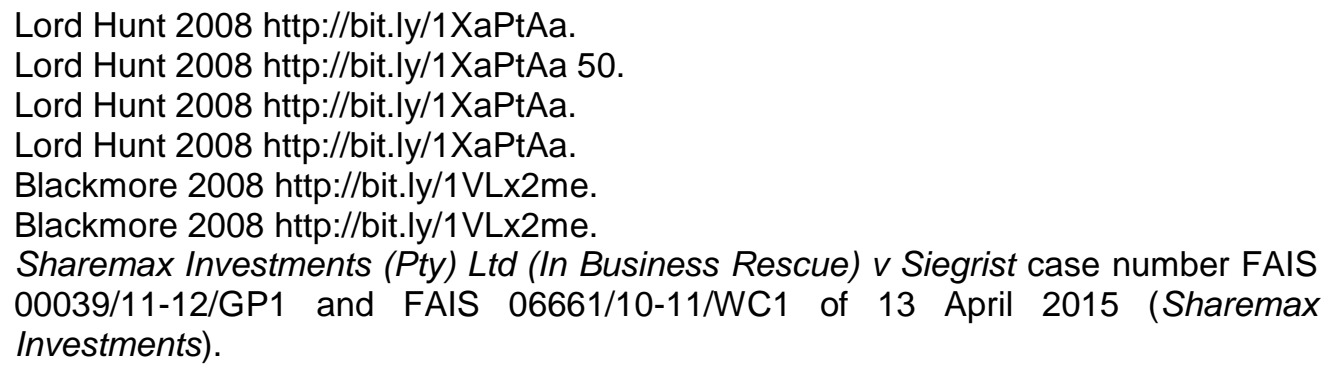


initiative, decided to join Sharemax and four of its former and present directors as defendants, because she regarded them as "interested parties" as described in section 27(4) of the FAIS Act. She subsequently denied the directors' leave to appeal against the decision, and when the Appeal Board agreed to hear the appeal, the issue of jurisdiction was one of the matters that was unpacked. The Appeal Board re-iterated that neither section 27(4) nor any other provision in the FAIS Act nor the rules that had been promulgated in terms of section 26(1) provides the Ombud with the power to join a defendant. ${ }^{35}$ The Appeal Board states very clearly that the complaint before the Ombud is the only issue that should be determined. It is not the Ombud's task to police financial services providers $^{36}$ and consequently the appeals were upheld and the orders against Siegrist and Bekker set aside.

\section{$4 \quad$ Fairness and law}

To return to the issue of fairness: although the Ombud must make a decision that is fair to all the parties involved, that does not mean that the Ombud should have a blatant disregard for South African law. In fact, the Appeal Board in Sharemax Investments found it disturbing that the Ombud was of the opinion that common-law principles have no place in proceedings before her. ${ }^{37}$ Although the Sharemax Investments case is fundamentally about jurisdiction and the Ombud's powers, it is very important to note that the Appeal Board also states that where there is a matter before the Ombud and it is based on the breach of a statutory duty, common-law principles apply. Similarly, where a matter hinges on breach of contract or delict, the Ombud should also have regard to common-law principles. Unfortunately, the rather short decisions by the Ombud often set out the facts and the decision, together with the relevant statutory principles, but all too often there is only mention of breach of the GCC and no investigation into matters such as breach of contract or negligence. The brief exposition below picks up on this issue.

\section{$5 \quad$ FSR Bill}

Among the many objectives of the FSR Bill there are specific ones that are aimed at providing for a more effective council for financial ombud services and for the council to oversee the ombud schemes. In addition,

Sharemax Investments paras 49 and 52.

Sharemax Investments para 16.

Sharemax Investments para 19. 
the Bill aims to provide for the "recognition of recognised schemes", ${ }^{38}$ to lay down minimum requirements for schemes, ${ }^{39}$ to promote financial customer education with regard to schemes, ${ }^{40}$ to co-ordinate the activities of ombuds of recognised schemes with the activities of the statutory ombud schemes, and to develop and promote best practices for complaint resolution. ${ }^{41}$

It is not clear how the Council who is to oversee the Ombud will make much of a difference. From the Sharemax debacle it is evident that the Appeal Board is currently equipped to overrule an inaccurate decision by the Ombud. In actual fact, the current appeal procedure should be more than adequate to ensure fairness in all respects. However, a closer look at the FSR Bill reveals a total overhaul of the current system. The Financial Services Ombuds Schemes $A c t^{42}$ will be repealed and integrated in the FSR Bill in such a way that the Financial Services Ombuds Schemes Council (FSOS Council) will have the power to consolidate and streamline ombuds arrangements more effectively. All existing ombuds will remain in place and will continue to function, but the FSOS Council will promote and direct co-operation and co-ordination of the activities of the schemes to achieve an overarching and unified complaint-resolution service for consumers. Clause 168 of the revised FSR Bill contains the new statutory provisions pertaining to the Council. ${ }^{43}$ The functions of the Council are provided for in clause 176 and this provision stipulates inter alia that the Council, in consultation with the relevant ombud, should develop and promote best practices for complaint resolution by a particular scheme. ${ }^{44}$ According to clause 176(2)(a), the Council must ensure that a council standard does not impede the independence of an ombud or interfere with the investigation or determination of a complaint.

Another change that will be introduced is that there will be an office of the Ombud for Financial Services Providers and the office of the adjudicator. ${ }^{45}$

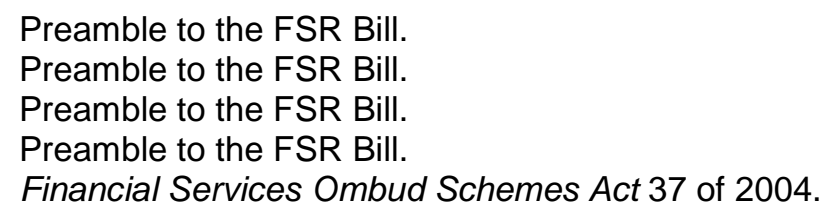

Clause 168 of the FSR Bill provides as follows: "(1) The Financial Services Ombud Schemes Council that was established in terms of section 2 of the Financial Services Ombud Schemes Act, 2004 (Act No. 37 of 2004), continues in existence. (2) The Council is an independent body that has the powers and duties, and performs the functions, that are set out in this Act. (3) The Council is directly accountable to the Minister."

44 Clause 176(1)(d) of the FSR Bill.

45 Clause 177 of the FSR Bill. 
Clause 180 stipulates that the objective of the Adjudicator and the Ombud for Financial Services Providers is

to consider and dispose of complaints in their respective spheres in a procedurally fair, informal, economical and expeditious manner and by reference to what is equitable in all the circumstances.

In doing so, they should have regard to the contractual arrangement or other legal relationship between the complainant and any other party to the complaint and the provisions of the FSR Bill, any other applicable law, conduct standard, codes of conduct, pension fund rules and rules of practice. These two spheres referred to are financial services as currently described by the FAIS Act on the one hand and pensions on the other hand.

Especially in the sense that the Adjudicator and Ombud should have regard to fairness, the relationship between the parties and the law, the FSR Bill seems to echo what is already contained in the FAIS Act and what has been blatantly disregarded by the FAIS Ombud in Sharemax. What is innovative though is that the revised FSR Bill imposes a duty on the regulators to co-operate with the Financial Intelligence Centre and otherwise assist in preventing and combating financial crime. Furthermore, clause 77 of the FSR Bill stipulates that the financial sector regulators and the Financial Intelligence Centre must enter into an agreement in respect to how they will co-ordinate the performance of their functions in terms of the Financial Intelligence Centre Act. $^{46}$

The problem with determinations as precedents has not been addressed by the FSR Bill. Section 186(1)(b)(iv) stipulates that the Ombud may make any other order which a court may make.

\section{$6 \quad$ More of the same?}

\subsection{General}

An overview of the activities of the FAIS Ombud for 2014 reveals that a variety of complaints were heard. Some of these dealt with important legal issues and considerations other than fairness should ideally have informed these issues. A summary of some of these cases will be given to illustrate this point.

46 Financial Intelligence Centre Act 38 of 2001. 


\subsection{Services under supervision and vicarious liability}

In Judith Augusta Theophiel Eduard Campioni-De Vleesshauwer v Suzette Brickhill and Mathys Johannes Marais t/a Protea Makelaars ${ }^{47}$ and Auberge Guest Lodge CC $v$ Suzette Brickhill and Mathys Johannes Marais t/a Protea Makelaars ${ }^{48}$ the Ombud ruled that Brickhill breached section 2 of the GCC because she failed to act with due skill, care and diligence and in the interests of clients and the integrity of the financial services industry. Brickhill rendered services under supervision and she had been in the employment of Marais (Protea Makelaars) since 1 May 2001. Despite Marais visiting Brickhill every six to eight weeks and performing an annual audit, Brickhill managed to defraud the two complainants in question. Brickhill persuaded new clients to pay annual premiums on their policies. She provided them with false invoices on Protea's letterhead. Brickhill did not keep these files in her office and Marais was ignorant of her activities. When he discovered her deceit, he immediately dismissed her. The Ombud had to decide two issues, namely whether there was sufficient evidence to find that Brickhill breached her duties in terms of the GCC by acting dishonestly and whether this caused the complainants in both cases to suffer financial loss. The second question was whether both Brickhill and Marais should be held liable.

The Ombud found that both complainants transferred their "annual premiums" to Brickhill. Neither Brickhill nor Marais had a mandate to collect premiums on behalf of Santam. Furthermore, the Ombud found on the facts that Marais allowed Brickhill to render financial services to the public whilst not being registered with the Registrar as his representative in terms of section 13 of the FAIS Act. Brickhill's rendering of services to the public was therefore not only a matter of her violating the law but also a transgression by Marais. Brickhill was not allowed to render services without supervision and that constituted a failure on Marais' behalf. As part of his ongoing obligation to supervise Brickhill, Marais should also have ensured that she complied with the GCC as required in terms of section 13(2)(b) of the FAIS Act. According to the Ombud, his failure to utilise resources, procedures and technological systems efficiently to prevent harm to clients rendered him liable. In both cases, the Ombud found that Brickhill rendered her services to the public for and on behalf of Marais

47 Judith Augusta Theophiel Eduard Campioni-De Vleesshauwer v Suzette Brickhill and Mathys Johannes Marais t/a Protea Makelaars case number FAIS 04437/1112/lp 3.

48 Auberge Guest Lodge CC v Suzette Brickhill and Mathys Johannes Marais t/a Protea Makelaars case number FAIS 05228/11-12/MP 3. 
and it was in the course and scope of her employment that Brickhill misappropriated insurance premiums. For these reasons the Ombud determined that Brickhill and Marais were jointly and severally liable to the complainants.

In this particular instance the Ombud's decision cannot be faulted, as the supervision of services plays an important role in the insurance industry. Those representatives who do not meet certain of the competency requirements must render services under the guidance, instruction and supervision of a supervisor. ${ }^{49}$ The rights and duties of the supervisor are accordingly specified. As far as the law is concerned, this particular case is an example of where a court would have determined the issue not only on the stipulations of the FAIS Act but also on the employer-employeerelationship that gives rise to vicarious liability. Matters such as the relationship between the parties (being one of employer and employee), the fact that Brickhill had possibly committed a delict, and the question whether she had acted in the scope of her employment are matters that would have been debated. Therefore, although the outcome of the two decisions in question was satisfactory, a proper exposition of Marais' direct and possibly vicarous liability would have been instructive. This proves the point that although decisions such as these are fair, they should not be usd as precedents. Unfortunately the FSR Bill does not change this.

\subsection{Incidentalia of insurance contracts and the duties of advisors}

The proverbial devil is in the detail, and because insurance is complex, prospective policyholders should ensure that they read an offer and acquaint themselves with the details before they enter into an insurance contract. Because of the asymmetry of information, there is a duty on intermediaries to explain the terms of the policy clients are about to procure. Onerous clauses are particularly problematic. In Fliptrans $C C \vee S$ \& $P$ Insurance Advisors (Pty) Ltd t/a McCrystal and Partners and $E$ Solmes, ${ }^{50}$ the dispute between the complainant and the respondents stemmed from the repudiation of a claim in terms of a short-term policy with New National. The policy was for the insurance of the complainant's motorcycle. The motorcycle was stolen on 9 July 2013 and the theft was reported to the respondents, S \& $P$ Insurance Advisors (Pty) Ltd t/a McCrystal and Partners and Elton Solms, the director of the first respondent. Essentially, the complainant's complaint is that the

49 BN 104 of 2008 in GG 31514 of 15 October 2008.

50 Fliptrans CC v S \& P Insurance Advisors (Pty) Ltd t/a McCrystal and Partners and E Solmes case number FAIS 07987/11-12/GP3. 
respondents as intermediaries failed to inform the complainant that the motorcycle had to be fitted with a tracking device. As a result, the complainant failed to fit such a device and this failure was the reason for New National's repudiation of the claim. In other words, had the complainant's attention been drawn to this particular requirement in the policy, he would have fitted the device and the claim would have succeeded. Accordingly, he would not have lost R79 500, which was the value of the motor cycle at the time of the loss.

The question in casu is essentially whether the respondent had failed in his duties as set out by section 7(1)(c)(vii) of the GCC. This subsection stipulates that a provider other than a direct marketer must provide, at the earliest possible opportunity, "concise details of any special terms or conditions, exclusions of liability, waiting periods, loadings, penalties, excesses, restrictions or circumstances in which benefits will not be provided". Insurance contracts are mosty standardised. Those who provide advice and intermediary services or at least earn commission for selling insurance have a duty to perform in terms of their mandate. In this particular case, the facts revealed that the insurance that was sold to the respondent was in fact incidental to the sale of his motor cycle and the respondent was in actual fact not involved in the transaction. He definitely did not provide advice and did not explain those onerous clauses in the contract.

This particular determination is no doubt fair. It follows other determinations such as Susanna Aletta Grobler v Direct Axis (Pty) Ltd ${ }^{51}$ and re-iterates the fact that intermediaries must sing for their supper. However, if one considers contract law and what constitutes consensus between the parties, several legal issues come to the fore. While the determination satisfies one's sense of fairness, there are several issues pertaining to consensus, pro-forma type contracts and vagueness of contractual terms that could have been better explained. Again, a determination such as the one in Fliptrans should not have been a precedent but could at the most have been presented as an example of what is expected of an insurance broker when selling a motor policy.

The exact same clause of the GCC was the subject of discussion in Andrew Graham Stunden and Nicolaas Leon van der Walt t/a Investment \& Insurance Brokers. ${ }^{52}$ In casu the complainant was the owner of a house

51 Susanna Aletta Grobler v Direct Axis (Pty) Ltd case number FOC 1434/05 NP 2.

52 Andrew Graham Stunden and Nicolaas Leon van der Walt t/a Investment \& Insurance Brokers case number FAIS 01993/11-12/WC 3 
in Knysna. The respondent was an insurance broker and a sole proprietor trading as Investment and Insurance Brokers. The respondent personally rendered financial services to the complainant and on the former's advice he placed his motor and household contents cover with Santam in 1999. When the complainant moved into a new house in June 2004, he again consulted with the respondent. He informed the respondent that his home had burglar bars on the ground floor windows only and that a linked alarm would be installed the following week. The respondent noted this and then proceeded to note the installation of the alarm the following week. The respondent and complainant met anually to adjust the insured values and other changes to the policy.

In July 2009 the insurer issued a notice to all brokers informing them that with effect from 1 September 2009 the security measures in the Knysna area would be burglar bars and security gates as well as a linked alarm. This notice further stated that Santam had experienced a high claims rate and urged brokers to infom their clients that alarms needed to be fitted. The complainant suffered a burglary at his home on 5 June 2010, and at the time only the ground floor windows were potected by burglar bars. The house was also protected by an alarm linked to an armed response. Santam established that the burglars gained access to the house through a top-floor window by using a long ladder. The window had not been protected by burglar bars. The alarm had been triggered when the burglary took place but the buglars escaped. The complainant's claim to Santam was rejected because he had not complied with the minimum security requirement of burglar bars on all windows. The essential question was whether the Respondent's conduct amounted to a contravention of the FAIS Act and the GCC and if so, whether this caused the complainant to suffer financial prejudice. The Ombud determined that there had in fact been a contravention of the GCC as the respondent had known about the insurer's new requirements but had in fact failed to convey the information to the complainant. What makes this determination different from the one in Fliptrans is that this case dealt with an existing contract for short-term insurance that had been in place for some time. The insurance company changed its requirements pertaining to burglar bars and the broker did not convey the information to the complainant. Situations such as these are perhaps not that easily explained in contract law. However, as this additional requirement by the insurer constitues a material change to the contract, it is submitted that it was absolutely essential for the broker to ensure that policyholders were informed of this 
change. This would have afforded them an opportunity to make an informed decision as to their contunued relationship withj the insurer.

Again, although the Ombud's decision satisfies one's sense of fairness, there are questions on contract law and the variation of contractual terms that are not addressed by this determination. On the facts it is evident that the respondent did not perform his duties as could be expected. It is submitted that a rules-based approach as is proposed by the FSR bill will have an influence on market conduct and that issues such as the nondisclosure of onerous terms will be more important. Matters such as plain language, consumer education and the format in which policies are presented to clients are expected to become more important, and TCF outcomes will influence traditional contract theory as we know it.

\section{$7 \quad$ Conducting business without a licence}

A recurring problem in the insurance industry seems to be the conducting of business without a licence. A person may not act or offer to act as a financial services provider unless such a person has been issued with a licence in terms of section 8 of the FAIS Act. ${ }^{53}$ Key to the granting of a licence is the question whether the applicant complies with the requirements of fit and proper in accordance with the category of FSP. The Registrar must consider issues such as operational ability, financial soundness, and whether the key individual meets the characteristics of honesty and integrity.

In The Reformed Christians for Truth Church $v$ Merit Legal and Funeral Cost Assistance (Pty) Ltd and Moeti Michael Matlaupane ${ }^{54}$ the complainant, represented by Pastor Paul Teko Mosadi, entered into an agreement in terms of which the respondent had to provide certain funeral benefits to members of the congregation against the payment of a monthly premium. At the outset of the respondents' dealings with the complainant, the respondents informed the complainants that the first respondent was underwritten by the South African Insurance Company (SAFRICAN) and that the first respondent was duly licenced by the Financial Services Board (FSB) in terms of the FAIS Act to render financial services to the public. The first respondent cited their registration number as 15123. In fact, this registration number belonged to SAFRICAN and the first respondent was

$53 \quad$ Moolman et al Financial Advisory and Intermediary Services Guide 17.

54 The Reformed Christians for Truth Church $v$ Merit Legal and Funeral Cost Assistance (Pty) Ltd and Moeti Michael Matlaupane case number FAIS 08606/1213/NW 2. 
not ever licenced to conduct insurance business. The parties agreed that the claimant would be paid within a period of 48 hours after the lodgement of a claim. The complainant paid the respondent the agreed monthly premiums. During December 2012 one of the complainant's congregants passed away. When no paymant was forthcoming, the complainant's investigation revealed that there had never been any insurance cover.

The Ombud's investigations confirmed that neither the first nor the second respondent were registered with the Financial Services Board and there was no evidence that the second respondent had ever been registered as an agent of a financial services provider. The respondent made the statements knowing well that he was acting illegally and that he had no intention of ever paying on any insurance claim. Therefore, the second respondent's conduct was both illegal in terms of the FAIS Act and unlawful in terms of common law. It seems that despite the strict regulatory environment, dishonest charlatans still manage to con members of the public.

In the same vein but pertaining to short-term insurance, some 22 determinations were made against Pieter De Wet ta Model Insurance Company, the first of which was made in favour of Melvin Shane Creswell. ${ }^{55} \mathrm{Mr}$ Creswell was one of a number of policy holders who approached the Ombud's office because the respondent failed to honour their claims. It appears that the respondent, Pieter de Wet t/a Model Insurance Company, presented himself to members of the public as as an authorised short-term insurer and he collected premiums from nonsuspecting consumers such as the complainant. The Registrar of Shortterm Insurance (Registrar) confirmed that the respondent had never been licensed in terms of section 7(1) of the FAIS Act to render financial services to the public. He had also never been licensed to conduct business as a short-term insurer as stipulated by section 7 of the STIA. This particular section stipulates as follows:

(1) No person shall carry on any kind of short-term insurance business unless that person-

(a) is registered or deemed to be registered as a short-term insurer, and is authorised to carry on the kind of short-term insurance business concerned under this Act; or

(b) is authorised under section 56 to do so, and carries on that business in accordance with this Act.

55 Melvin Shane Creswell v Pieter De Wet t/a Model Insurance Company Case number FSOS 00184/11-12/KZN(3). 
During February 2012 the Registrar warned the public not to do business with Model, and this particular saga is an example of where there is already a measure of information-sharing between the Registrar and the FAIS Ombud and of how the current FSB and the FAIS Ombud do have the opportunity to co-operate in a way that is not to the detriment of complainants or respondents but can in fact prevent members of the public from suffering financial prejudice. The respondent ignored this warning and continued to do insurance business without a licence. The Registrar then reported the respondent to the Commercial Crime Branch of the South African Police Service. In addition, the Registrar obtained an interim interdict in the Kwazulu-Natal High Court to stop the respondent from carrying out short-term insurance business.

The outcomes of all these cases were basically the same, namely that it was evident that the respondent carried on regardless of the Registrar's warnings. This caused financial prejudice to all the complainants involved.

Of course, in all the cases where members of the public were conned by unlicensed financial services providers, these complainants benefited from approaching the FAIS Ombud because their complaints could be dealt with expeditiously. Had court procedures been their only hope of claiming their losses, these procedures would have been costly and would in all likelihood have been delayed because the court rolls are so full. The Ombud serves a clear purpose here. Furthermore, the Ombud is in an ideal position to notify the Registrar as soon as it becomes evident that someone such as Pieter de Wet is providing financial services illegally. This is perhaps one of the greatest advantages of having a dedicated, alternative dispute resolution system such as the FAIS Ombud.

\section{Conclusion}

It is thought that the enhanced oversight of ombud schemes envisaged by the FSR Bill has the potential to adddress some of the challenges in insurance market conduct. These include stronger empowerment of the FSOS Council to consolidate and streamline Ombud determinations more effectively. ${ }^{56}$ Fairness has from the outset been one of the criteria for decisions by the FAIS Ombud, and even though the Ombud's determinations do not always deal with points of law in a very satisfactory way, many determinations do enforce the right of consumers of insurance products. Other than the streamlining of Ombud determinations and

56 National Treasury 2014 http://bit.ly/21B0sTU 14. 
oversight by the new FSOS Council, it seems that nothing much will change on this front with the introduction of the FSR Bill. Ombud determinations will still have the effect of court judgments and these will still be reported as precedents.

\section{PART III: PRUDENTIAL AUTHORITY}

\section{$1 \quad$ Background}

Generally speaking, prudential regulation and supervision aim to promote financial system stability and issues such as the solvency and liquidity of financial institutions are the focus of this function. ${ }^{57}$

One of the many functions of the prudential authority will be to undertake administrative and enforcement action as per chapters 12 and 13 of the FSR Bill, and "administrative action" has the meaning defined in section 1 of the Promotion of Administrative Justice Act. ${ }^{58}$ Chapter 13 of the FSR Bill sets out the powers of financial authorities to institute administrative action and according to clause $147(\mathrm{a})$ of the Bill.

The Promotion of Administrative Justice Act applies to any administrative action taken by a financial sector regulator in terms of this Act or a financial sector law subject to paragraph (c), which specifies that there may be different procedures for any specific administrative action provided that those procedures are fair, reasonable and justifiable in the circumstances.

There are further obligations on financial sector regulators to

put in place and maintain effective arrangements for taking administrative actions that are consistent with the FSR Bill, the Promotion of Administrative Justice Act, and the requirements of the other financial sector laws, which arrangements must include the adoption of administrative action procedures, and may include the establishment of an administrative action committee and other measures. ${ }^{59}$

57 National Treasury 2014 http://bit.ly/21B0sTU 10.

58 Promotion of Administrative Justice Act 3 of 2000. This statute defines "administrative action" as meaning any decision taken, or any failure to take a decision, by "(a) an organ of state, when - (i) exercising a power in terms of the Constitution or a provincial constitution; or (ii) exercising a public power or performing a public function in terms of any legislation; or (b) a natural or juristic person, other than an organ of state, when exercising a public power or performing a public function in terms of an empowering provision, which adversely affects the rights of any person and which has a direct, external legal effect". Clause $147(b)$ of the FSR Bill. 
It is foreseen that enforcement actions will mainly deal with the issuing of directives, entering into enforceable undertakings, declaring practices as undesirable, applying to court for appropriate orders, and imposing administrative penalties. Where the focus in the past has perhaps been more on penalties, that has now shifted and the FSR Bill states that remediation aims to rectify the breach and ensure it does not recur. In addition, and according to the principles of the promotion of administrative justice, chapter 15 sets out a strong appeal mechanism. Therefore, if the prudential authority detects a breach of a financial sector law, including of a prudential or conduct standard, it can choose to take remedial or punitive action. The FSR Bill provides the power to issue directives, enforceable undertakings, interdicts and debarment orders, and to impose administrative penalties.

These powers are not new to the regulatory authorities, and for the most part are a familiar feature of financial sector laws, but it is expected that administrative functions will be harmonised by the new legislative dispensation. Currently the FAIS Act contains detailed sections on offences and the payment of penalties which may be imposed by the Registar of the FSB. Any financial services provider that does not comply with its statutory duties may be penalised, and this function of the FSB is exercised by the Enforcement Committee. This Committee, which is an administrative body established in terms of the Financial Services Board Act 97 of 1990, is empowered to impose unlimited penalties, compensation orders and cost orders, and its determinations are enforceable as if they were a judgment of a court of law. The policing of the industry remains an important function and the FSR Bill provides inter alia for enforcement powers, the establishment of the Financial Services Tribunal, procedures for taking decisions and the appeal of these decisions.

According to National Treasury clear, transparent, fair enforcement mechanisms are a crucial part of an effective financial regulatory system. A Financial Services Tribunal is established to support fair administrative action and enforcement by the authorities. It is, however, not only the structure that will be reformed, but also the nature of regulation, supervision and enforcement. Therefore the new authorities "will be more proactive and intrusive in their supervision, and more principles-based in taking action where necessary". ${ }^{60}$

60 National Treasury 2014 http://bit.ly/21B0sTU 39. 
As far as administrative actions are concerned, the actions described below show that the Enforcement Committee usually acts where there is a breach of a particular rule. The FSR Bill, however, envisages for the new authority to "act decisively where necessary, at times on the basis of judgement rather than a formal 'breach' of a specific rule". 61

Therefore, the new definition of the difference between remedial and penalty actions perhaps signals the taking of a more innovative approach than the current approach, and directives and enforceable undertakings now also form part of the proposed new legislation. Where directives have been issued before, enforceable undertakings (EUs) are a new instrument for most sectors, although they have been introduced in the Financial Services Board Act recently. Clause 142 of the FSR Bill stipulates that a financial sector regulator may accept a written enforceable undertaking by a person in relation to any conduct engaged in by the person in respect of which the financial sector regulator has a function in terms of a financial sector law. The person may, with the regulator's consent, withdraw or vary the undertaking at any time. ${ }^{62}$ The crux of the concept legislation is found in clause 142(3), which stipulates as follows:

(3) If the financial sector regulator considers that the person who gave the undertaking has breached a term of the undertaking, the Financial Sector Regulator may:

(a) impose an administrative penalty;

(b) apply to a Court for an order directing that person to comply with the terms of the undertaking, or any other order the Court considers appropriate; or

(c) in the case of a licensed financial institution, suspend or withdraw the licence of the financial institution.

Furthermore, clause 142(4) holds that an enforceable undertaking must be made public by the financial sector regulator in a manner that the financial sector regulator determines is appropriate. The purpose of the new rules pertaining to an enforceable undertaking is that it provides the regulator with broad corrective powers under an agreement with the wrongdoer. It is expected that enforceable undertakings will set out detailed steps for correcting a deeply flawed aspect of a financial institution's process or system.

Court orders by the High Court to compel a financial institution to comply with a financial sector law, to compel compliance with a rule, directive or lawful request, remain part of the new prudential authority's armour.

61 National Treasury $2014 \mathrm{http} / / / \mathrm{bit} . l y / 21 \mathrm{~B} 0 \mathrm{sTU} 39$.

62 Clause 142(2) of the FSR Bill. 
What is different under the new Twin Peaks legislation is the new Financial Services Tribunal. The Tribunal's powers is set out in chapter 15 of the FSR Bill and clause 145 stipulates that the function of the Tribunal is to hear and decide appeals by persons aggrieved by a decision of a decision-maker in terms of a financial sector law. The Tribunal may also order a party to the appeal to pay some or all of the costs incurred by the other party. An order by the Tribunal has legal force, and may be enforced as if it were issued in civil proceedings in a division of the High Court. ${ }^{63}$

\section{Recent enforcement actions}

Over the past year, enforcement actions pertaining to insurance products were mostly satisfactory. Determinations included The Registrar of Financial Services Providers $v$ Finstate CC. ${ }^{64}$ In casu the Registrar's action against Finstate was based on two contraventions. The first was a contravention of section 13(2)(a) of the FAIS Act and the second a contravention of section 12(c) of the GCC. The parties agreed that both these provisions had been contravened and the agreed penalty was R40 000. More specifically, in this particular enforcement action some of Finstate's representatives rendered financial services during October 2011 and October 2012 in respect of health services benefits from Discovery. These representatives were not competent to render these services because they were not duly accredited in terms of regulation $28 \mathrm{~B}$ of the Medical Schemes Act 131 of 1998.

Section 13(2)(a) of the FAIS Act reads as follows:

An authorised financial services provider must at all times be satisfied that the provider's representatives, and the key individuals of such representatives, are, when rendering a financial service on behalf of the provider, competent to act, and comply with the requirements contemplated in paragraphs (a) and (b) of section 8(1) and subsection 1(b)(ii) of this section, where applicable.

The reference to section $8(1)$ is to the fit and proper requirements, which entail that financial services providers must comply with the characteristics of honesty and integrity, competence, operational ability and financial soundness. The second charge pertaining to the contravention of section 12(c) of the GCC entails Finstate's failure to structure its internal control procdures "so as to provide reasonable assurance that all applicable laws

$63 \quad$ National Treasury 2014 http://bit.ly/21B0sTU 42.

64 The Registrar of Financial Services Providers v Finstate CC case number 12/2013.

For a discussion of the case, see Millard 2014 JILB 1. 
were complied with". 65 Failure to do so resulted in a contravention of section 13(2)(a) of the FAIS Act. ${ }^{66}$

In The Registrar of Short-term Insurance $v$ The Lawyers Voice (Pty) Ltd ${ }^{67}$ there was a contravention of section $7(1)(a)$ of the STIA. This particular section provides that

no person shall carry on any kind of short-term insurance business, unless that person is registered or deemed to be registered as a short-term insurer, and is authorised to carry on the kind of short-term insurance business concerned, under this Act.

Where some contraventions are not so serious and do not cause harm to consumers of financial products, others have more serious implications. In The Registrar of Short-term Insurance $v$ Santam Ltd ${ }^{68}$ Santam authorised a small number of collecting agencies to collect premiums for short-term policies (personal lines) on its behalf between November 2008 and March 2013. In doing so Santam contravened several legislative provisions, including Directive 156.A.i (ST) read with section 4(2) of the STIA, section 45 of the STIA and regulations 4.1(1) and 4.1(2) of the Regulations in terms of the STIA. In addition, Santam failed to use the prescribed method in the STIA to calculate its unearned premium provision for its crop insurance class. (This particular contravention is of an actuarial nature and will not be discussed here.) The parties agreed that Santam would pay a fine of R200 000.69

The essence of the contravention is found in section 45 of the STIA, which states as follows:

No independent intermediary shall receive, hold or in any other manner deal with premiums payable under a short-term policy entered into or to be entered into with a short-term insurer, other than a short-term reinsurance policy, and no such short-term insurer shall permit such independent intermediary to so receive, hold or in any other manner deal with such premiums-

(a) unless authorised to do so by the short-term insurer concerned as prescribed by regulation; and

(b) otherwise than in accordance with the regulations.

\footnotetext{
65 Millard 2014 JILB 1-2.

66 Millard 2014 JILB 1-2.

67 The Registrar of Short-term Insurance $v$ The Lawyers Voice (Pty) Ltd case number 09/2013.

68 The Registrar of Short-term Insurance $v$ Santam Ltd case number 11/2013.

69 Millard 2014 JILB 3-4.
} 
Regulation 4.1(1) stipulates that a short-term insurer should authorise a collecting agency in writing to receive, hold or deal with premiums on its behalf, and regulation 4.1(2) requires an insurer to obtain securities from the collecting agencies. Not only did Santaim fail to provide written authorisation to these collecting agencies and to obtain securities, but it also failed to furnish the Registrar with proof of the written authorisation and securities in accordance with section 4(2) of the Short-term Insurance Act. This particular section, read with Directive 156.A.i (ST), instructs short-term insurers to provide the Registrar with an action plan to rectify the non-compliance with section 45 within 15 days from the date of informing the Registrar. ${ }^{70}$

This particular transgression highlights the important role of the Registrar in protecting the interests of policyholders and it illustrates the need for proper compliance measures. Because the collection of premiums is a core function of insurance business, it cannot be entrusted to just anybody and if a third party is entrusted with the collection of premiums, it is essential that that agreement complies with the stipulations of the STIA. This is an example of where the Enforcement Committee acted to penalise breach of a particular statutory provision.

In The Registrar of Financial Services Providers $v$ Hippo Comparative Services (Pty) Ltd, ${ }^{71}$ the respondent, through its call centre, provided financial services to members of the public betweeen 19 April 2011 and 7 September 2012. These services included the selling of short-term insurance policies on behalf of various short-term insurers. As part of these services the call center agents were also required to provide clients with different insurance quotations before selling a particular product. Unfortunately the call centre failed to provide clients with the complete lists of generated quotations and in some cases only provided clients with the cheapest quotations. This particular modus operandi resulted in "an approach in terms of which, in some cases, preference was given to the quantity of business over the quality of service rendered to clients". ${ }^{72}$ The parties agreed that the respondent's behaviour constituted a contravention of section $3 \mathrm{~A}(1)(\mathrm{b})(\mathrm{i})$ of the GCC. ${ }^{73}$ In addition to the contravention of

Millard 2014 JILB 3-4.

The Registrar of Financial Services Providers v Hippo Comparative Services (Pty) Ltd case number 08/2013 (Hippo Comparative Services).

72 See Millard 2014 JILB 6-7.

73 Section $3 A$ "Financial interest and conflict of interest management policy" of the GCC came into effect on 19 April 2011. S 3A(1)(b)(i) holds that a provider may not offer any financial interest to a representative of that provider for giving preference to 
section $3 A(1)(b)(i)$, it was also found that there was a contravention of section 15(1) of the GCC. This particular section stipulates as follows:

A direct marketer must, when rendering a financial service to or on behalf of a client, at the earliest reasonable opportunity furnish the client with the following particulars:
(a) the business or trade name of the direct marketer;
(b) confirmation whether the direct marketer is a licensed financial service provider and details of the financial services which the direct marketer is authorised to provide in terms of the license and any conditions or restrictions applicable thereto;
(c) telephone contact details of direct marketer (unless the contact was initiated by the client);
(d) telephone contact details of the compliance department of the direct marketer;
(e) whether the direct marketer holds professional and indemnity insurance.

The respondent failed to inform clients that it was a financial services provider. In addition, clients were also not informed of the details of the financial services that the respondent was authorised to provide and whether it held professional indemnity insurance. Its legal status and relationship with the various short-term insurance providers were also not disclosed. A penalty of R1 500000 was imposed. ${ }^{74}$

\section{Evaluation}

It is suggested that overall the Enforcement Committee's activities are already aimed at deterring financial services providers by imposing administrative penalties. Just administrative action is evident from the composition and activities of the Enforcement Committee and harsh penalties serve to protect the interests of consumers of financial services. Overall, the changes envisaged by the FSR bill are not expected to have much of an impact on insurance companies. Enforcement Action has been successful without too much bureaucratic red tape. More intergration and information sharing are matters that will be addressed by the Twin Peaks Bill.

the quantity of business secured for the provider to the exclusion of the quality of the service rendered to clients. 


\section{PART IV: COMMON LAW, INSURANCE LEGISLATION AND THE PRODUCT LIFE CYCLE}

As was stated above, the current dispensation for insurance allows for common-law principles as well as legislation, and products are grouped together as either short-term insurance or long-term insurance. Reinecke et al refer to this division as "curious and anachronistic". ${ }^{75}$ Matters were definitely complicated by the introduction of a special dispensation for insurance (and other) intermediaries and advisors by the FAIS Act and, as was argued above, the way in which the Ombud applies principles pertaining to fairness have definitely had implications for the way in which ordinary contractual principles are applied. The new dispensation is expected to muddle matters even further. Once TCF principles have become part of the new regulatory framework, courts will have to take this into account in deciding matters. This means that it will no longer be sufficient to apply the law, but courts will also have to measur the conduct of contracting parties against the TCF outcomes and in the light of the product-life cycle. It is suggested that it will no longer be possible to only consider the policy document as the record that sets out the rights and duties of the parties but that issues such as the way in which the product was advertised and sold will now also have to be considered.

Not only the TCF principles but also matters such as the disclosure of product information, claims handling, product standards and complaints that resort under market conduct will no doubt be more consumeroriented. It is an open question how courts will interpret TCF principles in disputes on insurance. It is not certain when the FSR Bill will become law. However, it is suggested that in the absence of new insurance legislation there will be interpretational issues that will make for some interesting reading.

The role of the courts in adjudicating insurance matters remains the same in the sense that any aggrieved party may approach a civil court with a dispute. An overview of the past year's cases reveals that recurring issues remain misrepresentation and the duty to disclose (Visser $v 1$ Life Direct Insurance Limited, ${ }^{76}$ Valoyi $v$ Absa iDirect Limited ${ }^{77}$ and Regent Insurance Co Ltd $v$ King's Property Development (Pty) Ltd t/a King's

\footnotetext{
75 Reinecke, Van Niekerk and Nienaber South African Insurance Law 10.

76 Visser v 1 Life Direct Insurance Limited (1005/13) 2014 ZASCA 193 (28 November 2014).

77 Valoyi v Absa Idirect Limited (27970/2011) 2014 ZAGPPHC 383 (12 June 2014).
} 
Prop). ${ }^{78}$ In addition, a number of cases addressed issues on the incidentalia or what are sometimes perceived as unfair, hidden clauses in insurance contracts, which cause costly litigation. There are many examples of incidentalia in insurance contracts, such as forfeiture clauses in the instance of fraud (see $P K$ Harikasun $v$ New National Assurance Company Ltd). ${ }^{79}$ The effect of a condition precedent was the topic under discussion in Screening and Earthworks (Proprietary) Limited $v$ Hollard Insurance Company Limited. ${ }^{80}$

However, it is suggested that the way in which the courts will apply the law as well as the fairness principles is an open question. Insurance remains complex and can be simplified only to a certain extent. Although the FAIS Ombud will be in a position to adjudicate on matters pertaining to insurance that concern the conduct of intermediaries and advisors, disputes between policyholders and insurance companies on matters such as those that have been mentioned in the previous paragraph still involve civil courts. It is not at all certain whether the principles that underlie current insurance law can always be related to an existing legal principle (statutory or otherwise)..$^{81}$

The remaining question that needs to be asked is whether the principles that underlie current insurance law can be related to an existing legal principle (statutory or otherwise). ${ }^{82}$ In order to answer this question, one should start by viewing the product life-cycle of a financial product. TCF holds that the real question whether a client has been treated fairly should always be answered by viewing the steps in the life-cycle, and these are as follows: product service and design, promotion and marketing, advice, point of sale, information after point of sale, and complaints handling. ${ }^{83}$

As far as product service and design are concerned, a clear legal framework as set out by the product-specific legislation (ie the LTIA and the STIA) is key. Currently these two statutes set out the definitions of products and prescribe the rules that are applicable. For instance, "assistance policy" means a life policy in respect of which the aggregate of

78 Regent Insurance Co Ltd v King's Property Development (Pty) Ltd t/a King's Prop 20153 SA 85 (SCA).

79 P K Harikasun $v$ New National Assurance Company Ltd (KZN) case number 190/2008 of 12 December 2013.

80 Screening and Earthworks (Proprietary) Limited $v$ Hollard Insurance Company Limited (2008/27712) 2014 ZAGPJHC 76 (4 April 2014).

81 On the impact of TCF on insurance contracts, see Millard 2014 THRHR 547-566.

82 On the impact of TCF on insurance contracts, see Millard 2014 THRHR 547-566.

83 In general, see Feasibility (Pty) Ltd 2010 http://bit.ly/1XaOyjd; and FSB 2011 http://bit.ly/1WLwQCm. 
the value of the policy benefits, other than an annuity, are to be provided (not taking into account any bonuses to be determined in the discretion of the long-term insurer) and the amount of the premium in return for which an annuity is to be provided does not exceed R18 000 or another maximum amount prescribed by the minister; and includes a re-assurance policy in respect of such a policy. ${ }^{84}$ According to Reinecke, Van Niekerk and Nienaber, an assistance policy may be described as a mini life policy. ${ }^{85}$ They argue that the prudential regulation applicable to insurers registered for assistance business is less onerous than for other business because those insurers are not permitted to issue policies with higher sums insured than those prescribed by statute. ${ }^{86}$ Setting a maximum on the amount payable in terms of a funeral policy is an example of how product service and design are already regulated by statute. It is expected that in future there will be even stricter product standards. One can therefore safely say that if an insurer issues a policy that is not defined in the enabling legislation, there is prima facie evidence of unfair treatment.

Promotion and marketing as the next stage in the product life-cycle may lead to difficulties. Currently, the GCC in terms of the FAIS Act contains standards on the advertising of insurance products. Despite this, it may still happen that there is something wrong with the advertisement and that this prompts a client to contact the insurer. The client may find that the product offered is not what the advertisement had promised. Although there is still such a thing as offer and acceptance and an insurer is free not to enter into a contract with the insurer, it often happens that where a contract is concluded, a client was promised one thing but then receives something entirely different. This in all likelihood amounts to unfair treatment. Again, the current legal framework already addresses this TCF outcome. The GCC defines "advertisement" as

any written, printed, electronic or oral communication (including a communication by means of a public radio service), which is directed to the general public, or any section thereof, or to any client on request, by any such person, which is intended merely to call attention to the marketing or promotion of financial services offered by such person, and which does not purport to provide detailed information regarding any such financial services. ${ }^{87}$

84 Section 1 of the LTIA, "assistance policy".

85 Reinecke, Van Niekerk and Nienaber South African Insurance Law 556.

86 Reinecke, Van Niekerk and Nienaber South African Insurance Law 556.

87 Section 1 of the GCC, "advertising". 
In addition, section 14(1) of the GCC contains detailed rules on advertising:

14(1) An advertisement by any provider must-

(a) not contain any statement, promise or forecast which is fraudulent, untrue or misleading;

(b) if it contains-

(i) performance data (including awards and rankings), include references to their source and date;

(ii) illustrations, forecasts or hypothetical data

(aa) contain support in the form of clearly stated basic assumptions (including but not limited to any relevant assumptions in respect of performance, returns, costs and charges) with a reasonable prospect of being met under current circumstances;

(bb) make it clear that they are not guaranteed and are provided for illustrative purposes only; and

(cc) also contain, where returns or benefits are dependent on the performance of underlying assets or other variable market factors, clear indications of such dependence;

(iii) a warning statement about risks involved in buying or selling a financial product, prominently render or display such statement; and

(iv) information about past performances, also contain a warning that past performances are not necessarily indicative of future performances; and

(c) if the investment value of a financial product mentioned in the advertisement is no guaranteed, contain a warning that no guarantees are provided.

(2) Where a provider advertises a financial service by telephone-

(a) an electronic, voicelogged record of all communications must be maintained. Where no financial service is rendered as a result of the advertisement, such record need not be maintained for a period exceeding 45 days;

(b) a copy of all such records must be provided on request by the client or the registrar within seven days of the request;

(c) all the information required by sections 4(1)(a) and (c) and 5(a) and (c) shall not be required: Provided that the client is provided with basic details (such as business name and telephone number or address) of the provider or relevant product supplier, and of their relevant compliance departments: Provided further that, if the promotion results in the rendering of a financial service, the full details required by those sections are provided to the client in writing within 30 days of the relevant interaction with the client.

(3) Where a provider advertises a financial service by means of a public radio service, the advertisement must include the business name of the provider.

This proves that existing law in many cases already contains principles of fairness.

Advice and point of sale may constitute different stages in the product lifecycle, but more than often these two stages are one and the same thing. "Advice" is already defined in section 1 of the FAIS Act, and this particular statute is very clear on the way in which advice should be furnished. In 
addition to these statutory obligations, there are common law rules pertaining to contract and specifically the duties of insurance brokers that essentially aim to protect the interests of prospective policyholders, thereby enhancing fairness. The duty of a broker to perform the mandate personally, to act with care and skill, and to act in good faith are some of the common law duties that still exist. ${ }^{88}$ The GCC contains quite a number of detailed rules that stipulate how an advisor and intermediary should conduct himself.

Information after point of sale is the second last stage in the product lifecycle. It is submitted that during this stage, it is either the insurer and the policyholder's relationship that is under scrutiny, in which case the LTIA or STIA and the respective Policyholder Protection Rules (PPR) in terms of each apply, or it is the relationship between an insurance broker and a client that is relevant, for instance where the broker continues to render ongoing services. In the latter instance the FAIS Act applies. There are a number of rules that may be identified in terms of the LTIA, STIA and FAIS Act that may apply and that exist to protect the policyholder. For instance, rule 7.4 of the PPR's terms of both the LTIA and the STIA deal with time bar clauses and contain specific provisions on the periods within which a claim can be brought and the time within which a dissatisfied policyholder may bring an action against an insurer. There are many other examples that cannot be discussed here.

The matter of bringing an action brings us to the final stage in the product life-cycle, namely complaints handling. Part XI of the GCC in terms of the FAIS Act already specifies that the FSP should have an internal dispute resolution system. ${ }^{89}$ These and other rules are aimed at treating the customer fairly.

Overall, it is clear that existing common law rules and legislation provide policyholders with a variety of rights. It is suggested that fairness is already infused in insurance legislation, and although there are areas such as credit insurance and onerous terms in insurance contracts that need reform, TCF throughout the product life-cycle is not really anything new.

\section{Conclusion}

The activities of insurers, intermediaries and advisors over the past year reveal the many issues and complexities that make up insurance

88 Havenga Law of Insurance Intermediaries 3-4.

89 See $\mathrm{s} 19$ of the GCC for the specific obligations. 
business. Insurance as a financial product is complex and, as was seen in the FAIS Ombud and Enforcement Committee cases, there is a definite need to promote and enhance consumer protection. It is anybody's guess, however, whether more bureaucratic arrangements as per the FSR Bill will in fact achieve this objective.

\section{Bibliography}

\section{Literature}

Havenga Law of Insurance Intermediaries

Havenga P The Law of Insurance Intermediaries (Juta Cape Town 2001)

Millard 2014 THRHR

Millard D "Through the Looking Glass: Fairness in Insurance Contracts - A Caucus Race?" 2014 THRHR 547-566

Millard 2014 JILB

Millard D "Enforcement Actions" 2014 JILB vol 17 no 1 1-2

Moolman et al Financial Advisory and Intermediary Services Guide Moolman $\mathrm{J}$ et al Financial Advisory and Intermediary Services Guide (LexisNexis Durban 2010)

Reinecke, Van Niekerk and Nienaber South African Insurance Law Reinecke MFB, Van Niekerk JP and Nienaber PM South African Insurance Law (LexisNexis Durban 2013)

\section{Case law}

Andrew Graham Stunden and Nicolaas Leon van der Walt ta Investment \& Insurance Brokers_case number FAIS 01993/11-12/WC 3

Auberge Guest Lodge CC v Suzette Brickhill and Mathys Johannes Marais t/a Protea Makelaars case number FAIS 05228/11-12/MP 3

Fliptrans CC v S \& P Insurance Advisors (Pty) Ltd t/a McCrystal and Partners and $E$ Solmes case number FAIS 07987/11-12/GP3

Judith Augusta Theophiel Eduard Campioni-De Vleesshauwer v Suzette Brickhill and Mathys Johannes Marais t/a Protea Makelaars case number FAIS 04437/11-12/lp 3 
P K Harikasun $v$ New National Assurance Company Ltd (KZN) case number 190/2008 of 12 December 2013

Regent Insurance Co Ltd $v$ King's Property Development (Pty) Ltd t/a King's Prop 20153 SA 85 (SCA)

Screening and Earthworks (Proprietary) Limited $v$ Hollard Insurance Company Limited (2008/27712) 2014 ZAGPJHC 76 (4 April 2014)

Sharemax Investments (Pty) Ltd (In Business Rescue) v Siegrist case number FAIS 00039/11-12/GP1 and FAIS 06661/10-11/WC1 of 13 April 2015

Susanna Aletta Grobler v Direct Axis (Pty) Ltd case number FOC 1434/05 NP 2

The Reformed Christians for Truth Church v Merit Legal and Funeral Cost Assistance (Pty) Ltd and Moeti Michael Matlaupane case number FAIS 08606/12-13/NW 2

The Registrar of Financial Services Providers v Finstate CC case number $12 / 2013$

The Registrar of Financial Services Providers $v$ Hippo Comparative Services (Pty) Ltd case number 08/2013

The Registrar of Short-term Insurance $v$ Santam Ltd case number 11/2013 The Registrar of Short-term Insurance $v$ The Lawyers Voice (Pty) Ltd case number 09/2013

Valoyi v Absa Idirect Limited (27970/2011) 2014 ZAGPPHC 383 (12 June 2014)

Visser v 1 Life Direct Insurance Limited (1005/13) 2014 ZASCA 193 (28 November 2014)

\section{Legislation}

Financial Advisory and Intermediary Services Act 37 of 2002

Financial Intelligence Centre Act 38 of 2001

Financial Services Board Act 97 of 1990 
Financial Services Ombud Schemes Act 37 of 2004

Long-term Insurance Act 52 of 1998

Medical Schemes Act 131 of 1998

Promotion of Administrative Justice Act 3 of 2000

Short-term Insurance Act 53 of 1998

\section{South African government publications}

Board Notice 104 of 2008 in GG 31514 of 15 October 2008.

Financial Sector Regulation Bill [B34-2015]

\section{Internet sources}

Blackmore $2008 \mathrm{http}: / /$ bit.ly/1VLx2me

Blackmore N 2008 AIFA Fears Second Tier Regulation Via FOSBook http://bit.ly/1VLx2me accessed 1 July 2011

Feasibility (Pty) Ltd 2010 http://bit.ly/1XaOyjd

Feasibility (Pty) Ltd 2010 Treating Customers Fairly: A Discussion Paper Prepared for the Financial Services Board http://bit.ly/1XaOyjd accessed 11 August 2013

FSB 2011 http://bit.ly/1WLwQCm

Financial Services Board 2011 Treating Customers Fairly: The Roadmap 2011 http://bit.ly/1WLwQCmaccessed 11 August 2013

Gilmour 2015 http://bit.ly/1T3KeT8

Gilmour J 2015 2014's Twin Peaks - No, It's Not Next Year's Play Boy Calendar... http://bit.ly/1T3KeT8 accessed 5 May 2015

Lord Hunt 2008 http://bit.ly/1XaPtAa

Lord Hunt 2008 Opening Up, Reaching Out and Aiming High: An Agenda for Accessibility and Excellence in the Financial Ombudsman Service http://bit.ly/1XaPtAa accessed 5 May 2015

National Treasury 2014 http://bit.ly/21B0sTU

National Treasury 2014 Twin Peaks in South Africa: Response and Explanatory Document Accompanying the Second Draft of the Financial Sector Regulation Bill http://bit.ly/21B0sTU accessed 5 May 2015 
National Treasury 2014 http://bit.ly/26XEGxB

National Treasury 2014 Financial Sector Regulation Bill - Comments Received on the First Draft Bill Published by National Treasury for Comments in December 2013 http://bit.ly/26XEGxB accessed 5 May 2015

National Treasury 2014 http://www.treasury.gov.za/public\%20comments/ FSR2014/Treating\%20Customers\%20Fairly\%20in\%20the\%20Financial\% 20Sector\%20Draft\%20MCP\%20Framework\%20Amended\%20Jan2015\%2 OWithAp6.pdf

National Treasury 2014 Treating Customers Fairly in the Financial Sector: A Draft Market Conduct Policy for South Africa - Discussion Document http://www.treasury.gov.za/public\%20comments/FSR2014/Treating\%20Cu stomers\%20Fairly\%20in\%20the\%20Financial\%20Sector\%20Draft\%20MC P\%20Framework\%20Amended\%20Jan2015\%20WithAp6.pdf accessed 4 May 2015

\section{List of Abbreviations}

ASISA

EUs

FAIS Act

FIA

FSB

FSCA

FSR

FSOS

GCC

JILB

LTIA

PPR

SAFRICAN

SAIA

STIA

TCF

THRHR
Association for Savings and Investment

South Africa

Enforceable undertakings

Financial Advisory and Intermediary Services Act 37 of 2002

Financial Intermediaries Association of Southern Africa

Financial Services Board

Financial Sector Conduct Authority

Financial Sector Regulation

Financial Services Ombuds Schemes

General Code of Conduct for Authorised Financial Services Providers and Representatives Juta's Insurance Law Bulletin

Long-term Insurance Act 52 of 1998

Policyholder Protection Rules

South African Insurance Company

South African Insurance Association

Short-term Insurance Act 53 of 1998

Treating Customers Fairly

Tydskrif Vir Hedendaagse Romeins-Hollandse Reg / Journal of Contemporary Roman Dutch Law 
